Article

\title{
Experimental Study on the Performance of Polyurethane-Steel Sandwich Structure under Debris Flow
}

\author{
Peizhen $\mathrm{Li}^{1,2}$ (D), Shutong Liu ${ }^{2}$ and Zheng Lu ${ }^{1,2, *}$ \\ 1 State Key Laboratory of Disaster Reduction in Civil Engineering, Tongji University, Shanghai 200092, China; \\ lipeizh@tongji.edu.cn \\ 2 Research Institute of Structural Engineering and Disaster Reduction, Tongji University, Shanghai 200092, \\ China; liushutong@tongji.edu.cn \\ * Correspondence: luzheng111@tongji.edu.cn; Tel.: +86-21-6598-6186
}

Received: 7 September 2017; Accepted: 29 September 2017; Published: 2 October 2017

\begin{abstract}
Polyurethane-steel sandwich structure, which creatively uses the polyurethane-steel sandwich composite as a structural material, is proposed to strengthen the impact resistance of buildings under debris flow. The impact resistance of polyurethane-steel sandwich structure under debris flow is investigated by a series of impact loading tests, compared with that of traditional steel frame structures. Additionally, further discussions regarding the hidden mechanism are performed. During the whole impact process, as for steel frame structure, the impacted column appeared obvious local deformation both at its column base and on the impact surface, leading to remarkable decrease of its impact resistance; while the stress and strain of polyurethane-steel sandwich structure develops more uniformly and distribute further in the whole structure, maintaining excellent integrity and impact transmission capability. The impact loading tests confirm that polyurethane-steel sandwich structure possesses superior impact resistance under debris flow. This is of great practical significance for the prevention and reduction of geological disasters.
\end{abstract}

Keywords: polyurethane-steel sandwich structure; debris flow; impact loading tests; impact resistance

\section{Introduction}

Debris flows are gravity-driven surges of roughly equal volumes of water and poorly sorted sediment, thoroughly mixed and agitated [1], characterized as being large-scale, unpredictable, and extremely destructive. The mountainous areas with low vegetation coverage are highly prone to debris flow hazards [2]. Many catastrophic debris flow disasters, resulting in heavy casualties and massive property losses, have been reported across the world (debris flows on 7 August 2010 in Zhouqu [2], 1998 volcaniclastic debris flows in the Sarno area [3], 2013 Wulipo landslide, and the resulting debris flow in Dujiangyan City [4]). Compared with strong structural facilities, such as railway bridges, common residential buildings are more easily damaged by debris flows. Moreover, most deaths and property losses are associated with the damage to buildings. For this reason, it is an urgent issue to study the dynamic response of structures under debris flow and take effective measures to increase their resistance to such disasters.

Impact force is the most important index and foundation for engineering design and risk assessment to buildings by debris flow. Additionally, it is the theoretical basis of the study on the impact of debris flow on structures [5-11]. In recent decades, several simplified analytical methods have been provided in the published literature to investigate the impact force of debris flow. Chen et al. [12] simplified the debris flow as two-phase fluid, establishing method to calculate velocities of solid phase and liquid phase of debris flow. Hungr et al. [13] provided a quantitative approach to calculate the 
impact force of debris flow, by means of simplifying the collision between stone and the retaining structure as the impact of rock on a cantilever beam. Moriguchi et al. [14] conducted small-scale laboratory physical modeling and corresponding numerical simulations in the Eulerian framework to estimate the impact force generated by granular flow. Some scholars simulated the flow behavior of debris flows by the smoothed particle hydrodynamics (SPH) method and have made promising progress [15-17]. Dai et al. [18] put forward a fluid-structure coupled numerical model based on SPH to predict the propagation and impact force of debris flows.

The time-frequency analysis of the impact fluctuation signals of debris flow would provide a meaningful basis for the study of debris flow load. A few field tests and field observations have also been reported. For example, Hu et al. [19] measured the first time a long-duration series of impact force at different flow depths, founding that the peak grain impacts at different depths were non-synchronous within the debris flows. Chen et al. [20] conducted debris flow tests of different solid and particle size combinations, and finally obtained the energy intensity of shock loading in different frequency bands using wavelet time frequency analysis.

In addition, analyzing potential damage of residential buildings to debris flow hazards is essential to study the impact of debris flow on structures. Although some progress has been made in quantifying the vulnerability of buildings to debris flows in many countries [21-23], field observations, experimental studies, and numerical simulations on the failure mechanism and impact resistance of engineering structures under the impact of debris flow are highly necessary. Zeng et al. [24] classified the failure models of reinforced concrete columns based on field investigation, and studied collapse mechanism for columns damaged by debris flow. Zhang et al. [25] carried out experimental research on reinforced concrete buildings struck by debris flow, collecting and analyzing experimental data. Hu et al. [2] distinguished the characteristics and patterns of damage to buildings by debris flows on 7 August 2010 in Zhouqu. Zanchetta et al. [3] assessed the relationship between the debris flow impact and structural damage in 1998 Sarno volcaniclastic debris flows.

To attenuate the dynamic impact force generated by debris flow and mitigate the subsequent destructive effects, many debris flow prevention and control engineering, such as debris flow barriers, debris racks and fences, debris-flow retention structures and debris breakers [26-30], are applied. Nevertheless, present design of these structures usually refers to empirical models [31]. As a result, the structures are often destroyed during the debris flow disasters. A sudden breakage of the protective structures would increase the destructive power of the debris flow and result in a more serious disaster, thus relying solely on the protective structure is inadvisable, and it is particularly critical to improve the impact resistance of the structure itself, which is the last line of defense against the impact of debris flow. Some innovative methods and concepts have been presented. For example, Li et al. [32] presented a novel masonry structure with strong resistance to debris flow; Lu et al. [33] proposed a shock absorption buffer to reduce the vulnerability of building structures under debris flows.

The impact resistance of traditional building material, like steel and masonry, could not fully meet the demand of resisting debris flow impact. With the progress of materials science and manufacturing technology, and the diversification of engineering requirements for materials, a polyurethane-steel sandwich composite emerges, in which the core material (polyurethane elastomer) and the steel plate are bonded by strong glue, or the polyurethane elastomer is directly poured into the hollow steel plate component. The polyurethane-steel sandwich composite is not only characterized by high strength and stiffness, but also has the advantages of light weight, easy processing, fire resistance, impact resistance, and fatigue endurance [34,35]. At present, the polyurethane-steel sandwich composite is widely used in ship engineering, sports venue construction, bridge pier anti-collision, as well as the bridge deck laying and repairing [36-40].

Although the polyurethane-steel sandwich composite has been applied in engineering in recent years, it is still rare to be used as a structural material for buildings. Moreover, it has a bright engineering application prospect to be widely used as the building material in debris flow prone areas due to its excellent impact resistance. In this paper, polyurethane-steel sandwich structure is proposed 
by columns that are filled with polyurethane elastomer to improve the impact resistance of traditional steel frame structures. The main objectives are to further assess the dynamic impact response and the impact resistance of building structure which uses the polyurethane-steel sandwich composite as structural material under the impact of debris flow. Based on field tests, the performance analysis and comparison of the polyurethane-steel sandwich structure to an ordinary steel frame structure under the impact of simulated debris flow are conducted, and the hidden mechanisms are also discussed.

\section{Test Setup and Procedure}

\subsection{Test Model}

The experiment is carried out by two test models fixed up on the platform, which are a two-story steel frame structure (Model A) and a polyurethane-steel sandwich structure (Model B), respectively. Compared with steel frame structure, polyurethane-steel sandwich structure's columns in the impact direction of debris flow, are filled with polyurethane elastomer, as shown in Figure 1a-c. In order to make the polyurethane elastomer a solid and bond the steel column together, the polyurethane-steel sandwich column is heated after the liquid polyurethane elastomer is poured in the steel pipe column. The height of first floor is $1.0 \mathrm{~m}$ and that of the second floor is $0.75 \mathrm{~m}$. The test model in the present study is scaled down from full-scale buildings based on similitude principles. The model's scale is $1 / 4$. Table 1 lists the specific parameters of various members. Figure $1 \mathrm{~d}$,e show the structural layout of Model B and photo of test model, respectively.

Table 1. Specific parameters of members.

\begin{tabular}{ccc}
\hline Member Name & Material & Member Dimension (mm) \\
\hline GKZ1 & & $\square 100 \times 100 \times 3 \times 3$ \\
\hline GKZ2 & \multirow{2}{*}{ Q235 } & $\square 100 \times 100 \times 3 \times 3$ \\
\hline GKL1 & & $H 125 \times 50 \times 2 \times 3$ \\
\hline GL1 & & $H 100 \times 50 \times 2 \times 3$ \\
\hline
\end{tabular}

\subsection{Test Loading Schedule}

In this test, referring to other experts' experience [25,41], the load of debris flow is simulated by an impact force caused by a steel ball rolling down in the slope track. The effective sliding height of the steel ball is chosen as $2.5 \mathrm{~m}$, and the loading height is set to $1 / 2$ floor height above ground [42]. A / 2 column is the column directly subjected to the impact loading, as shown in Figure $1 \mathrm{~d}$. The different diameters of steel balls are used to simulate the impact loads, for the sake of hierarchical loading. The complete loading sequences are summarized in Table 2, which consists of six loading levels that are labeled from case G1 to G6. Figure 1f-h displays the elevation of loading device, photo of the test site and 3D schematic of the entire structure, respectively.

Table 2. Test loading schedule.

\begin{tabular}{ccccc}
\hline Loading Case & Diameter of the Steel Ball/mm & Mass of the Steel Ball/kg & Impact Velocity/m/s & Impact Energy/J \\
\hline G1 & 200 & 33 & 7 & 808.5 \\
G2 & 300 & 111 & 7 & 2791.5 \\
G3-G6 & 350 & 180 & 7 & 4410 \\
\hline
\end{tabular}

\subsection{Instrumentation Arrangement}

As depicted in Figure 2a,b, strain gauges are used to measure the structural strain, among which there are fifteen one-way strain gauges and ten three-way strain gauges. Additionally, nine displacement meters are used to measure the displacement at the impact position and the displacement at the top of each floor of the impacted column and columns adjacent to the impacted column $(\mathrm{A} / 1$, 
$\mathrm{A} / 3$, and $\mathrm{C} / 2$ column). At the same time, the acceleration response at the impact position and the acceleration response at the top of each floor of $\mathrm{A} / 3$ column are measured by three accelerometers. Figure $2 \mathrm{c}$ displays the arrangement of displacement meters and accelerometers.

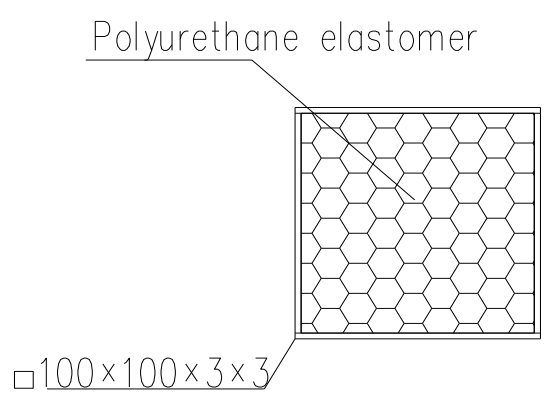

(a)

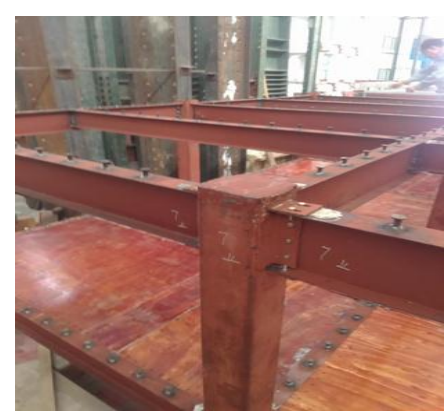

(c)

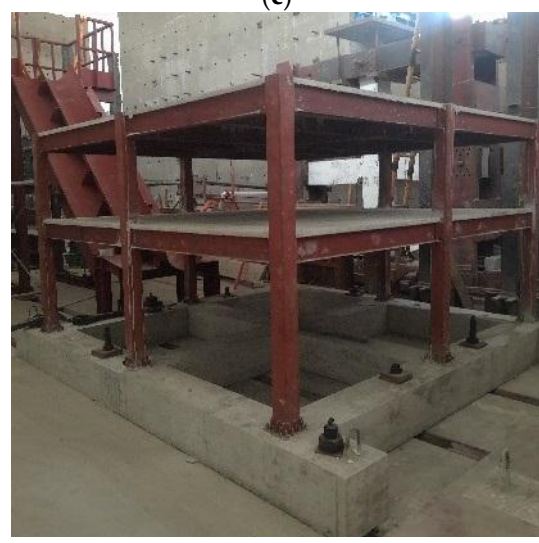

(e)

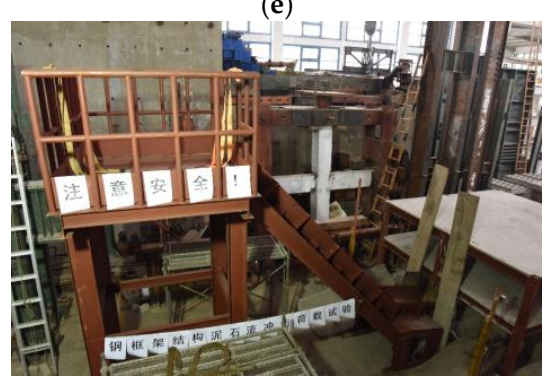

(g)

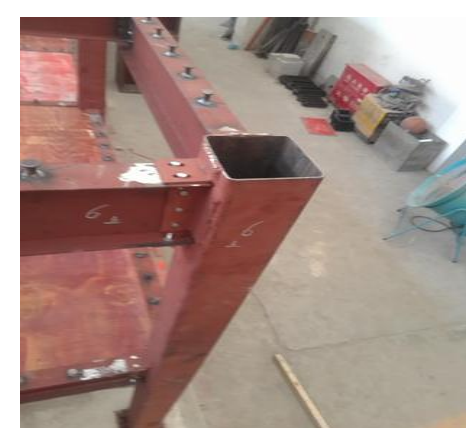

(b)

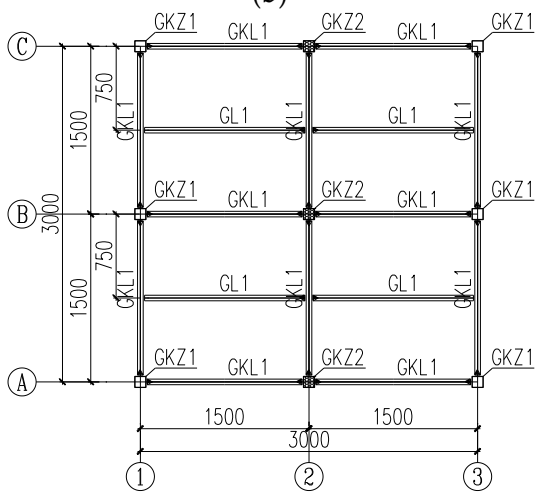

(d)

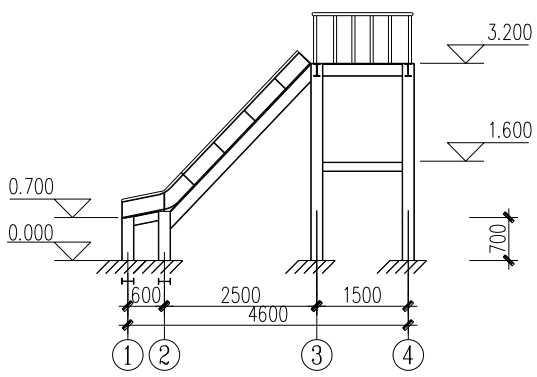

$(\mathbf{f})$

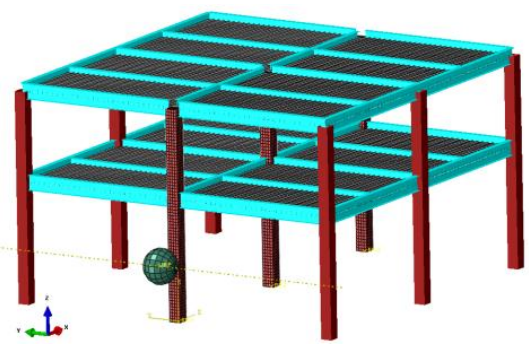

(h)

Figure 1. (a) Schematic diagram of the polyurethane-steel sandwich column; (b) photo of steel frame column; (c) photo of polyurethane-steel sandwich column; (d) the structural layout of Model B; (e) photo of test model; (f) elevation of loading device; (g) photo of the test site; and (h) a 3D schematic of the entire structure. 


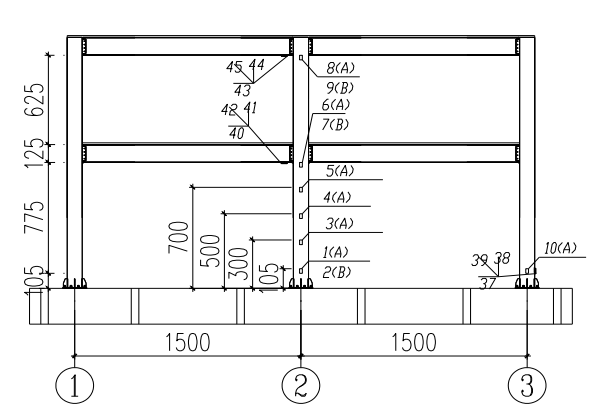

(a)

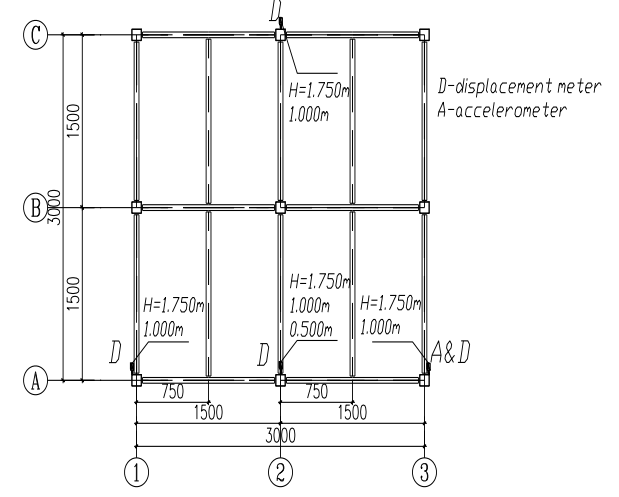

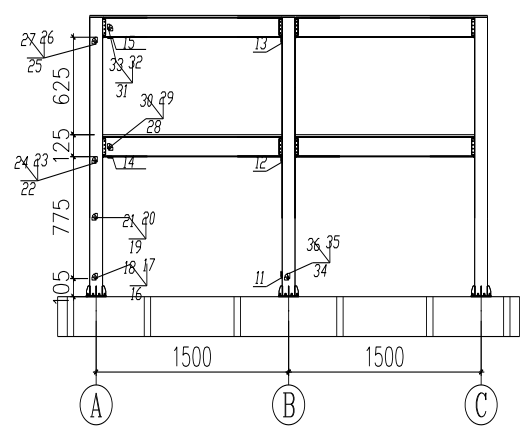

(b)

(c)

Figure 2. Instrumentation arrangement. (a) Strain gauge arrangement of axis $A ;(b)$ strain gauge arrangement of axis 2; and (c) displacement meter and accelerometer arrangement.

\subsection{Polyurethane Property Test}

Six uniaxial compression specimens are casted when the frame columns are filled, and its uniaxial compression tests are conducted. The stress-strain relationship of the polyurethane elastomer is shown in Figure 3.

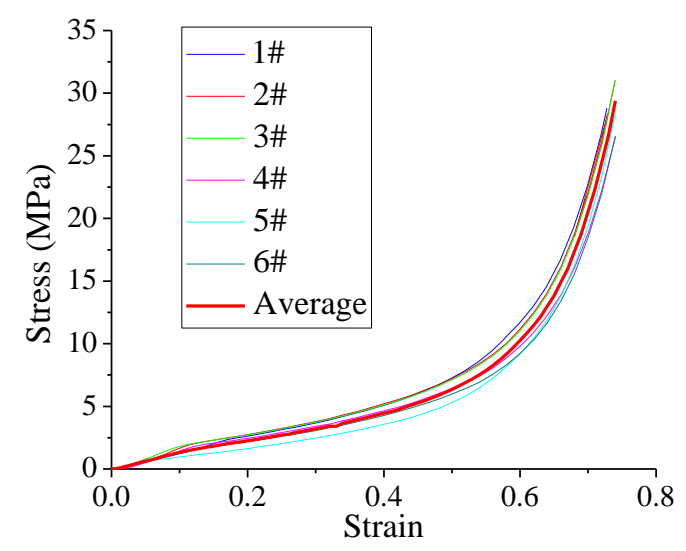

Figure 3. The stress-strain relationship of polyurethane elastomer in the test.

\section{Test Phenomena and Analysis}

In this section, through the test data and test phenomena, the impact responses of the polyurethane-steel sandwich structure and steel frame structure are analyzed and compared, from the impacted column to the overall structure, and some valuable conclusions are drawn. In consideration of debris flows' features of high velocity, extreme impact force, and severe damage, this study is focused on peak response. 


\subsection{Response of the Impacted Column}

After the end of each impact, the local deformation of steel frame structure is significantly larger than that of the polyurethane-steel sandwich structure. The column's impacted surface of steel frame structure appeared deep dent and its both sides warped badly. Its local bending deformation is quite large. As shown in Figure 4, the column surface near the impact position of the steel frame structure is slightly cracked after case G3.

According to Figure 5a, it is noteworthy that the total value and incremental value of Model A's dent-depth are far greater than those of Model B's. This is because the columns of the polyurethane-steel sandwich structure are filled with a polyurethane elastomer that has low compression characteristics, which strengthens the structural integrity, hence, it can coordinate the whole force and deformation in the column. The polyurethane elastomer is bonded with the steel column to ensure a reliable connection, and it could transmit the shear force further and ensure the integrity of column against the impact force. Meanwhile, it also acts as a buffer against the impact force.

Figure $5 \mathrm{~b}$ illustrates the displacement time-history of the impact position's back surface under case G6. The results clearly demonstrate that the displacement of Model B at that position is much larger than that of Model A. The reason for this phenomenon is that polyurethane elastomers are fully extruded, and the impact force is transmitted to the column's back surface by polyurethane elastomer. As to steel frame structure, its column completely relied on the side plate to transmit the impact force to its back surface, and its load transferring path is not direct, forming quite a large dent on the impact surface and a relatively small displacement on its back surface.

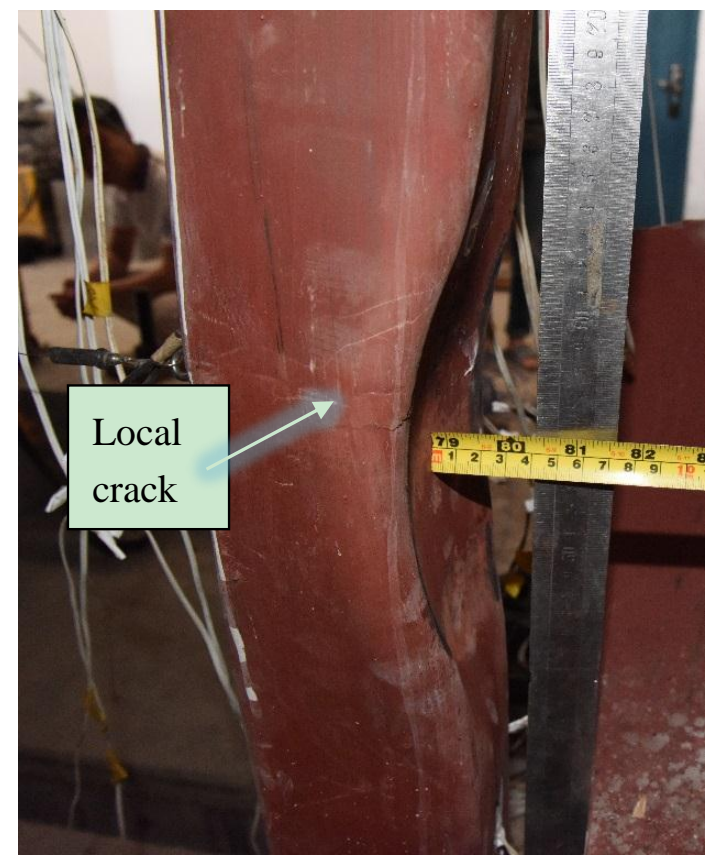

(a)

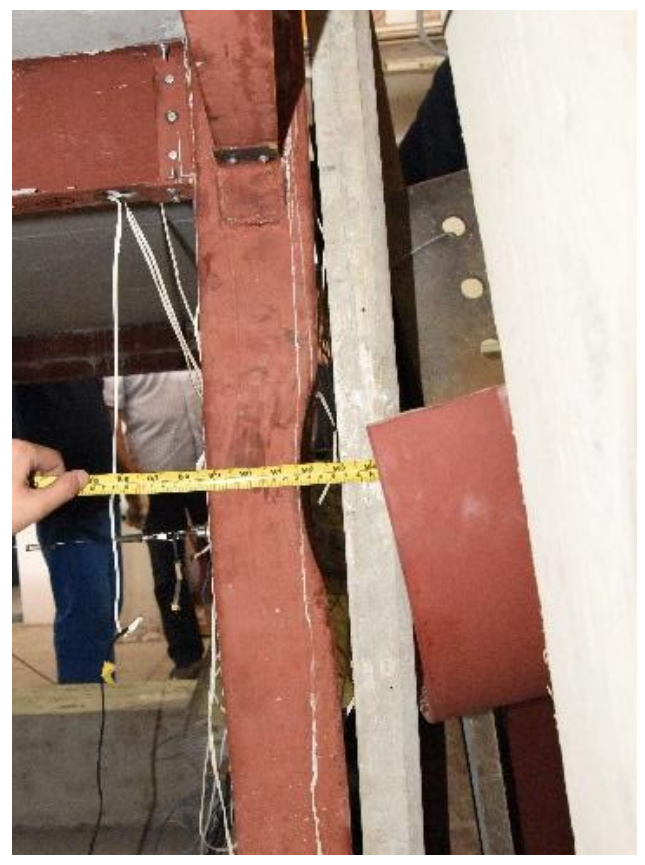

(b)

Figure 4. Photo of the impacted column after case G3: (a) Model A; and (b) Model B.

By comparing Figure 5a,b, at the end of case G6, it is evident that the displacement of the impact surface of Model A is relatively large while that of its back surface is small. However, the law of Model B is opposite to Model A. Accordingly, after case G6, the distance between the impact position and its back surface of Model A column is smaller than that of Model B's column, and the difference between the two models is about $30 \mathrm{~mm}$. The decrease of distance between the impact position and its back surface means the decrease of section's bending arm and bending modulus. Consequently, the bending resistance of steel frame structure's column is evidently reduced. Furthermore, under the 
impact loading of debris flow, the midspan of the column is the key position to resisting the bending moment. The increase of the horizontal displacement at the midspan of column would also cause the second-order effect of gravity load to increase remarkably, even triggering the overall collapse of the structure, causing serious economic losses and casualties.

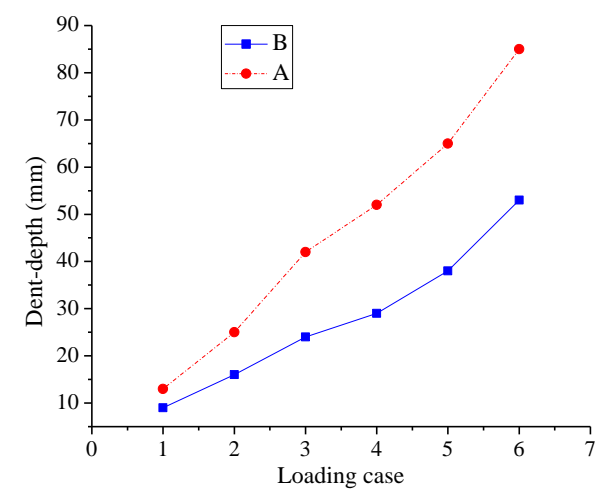

(a)

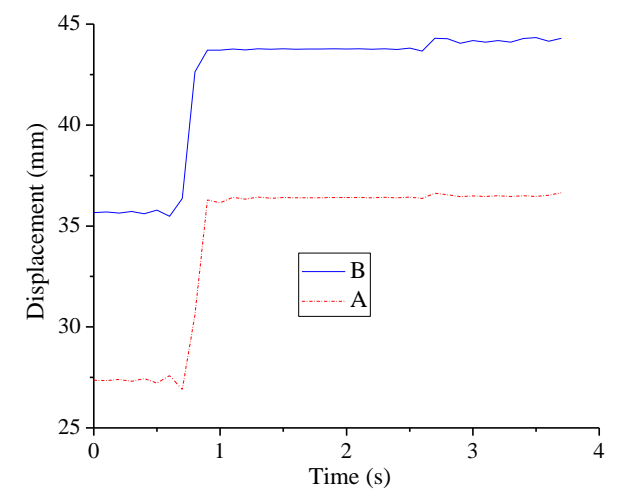

(b)

Figure 5. (a) Dent-depth at the impact position; and (b) the displacement time-history of the impact position's back surface under case G6.

Figure 6 shows the maximum normal strain at back surface of the impact position and the maximum shear strain at the corresponding side plate of the impacted column. It can be seen that the maximum normal strain of Model $B$ at the back surface of the impact position is larger than that of Model A; for the maximum shear strain of the side plate, that of Model A is relatively larger. According to the analysis of the previous test phenomenon and the measured displacement, owing to the low compressibility of polyurethane elastomer and the reliable bonding between the column and polyurethane elastomer, the impact force on the impacted column could be transmitted directly to the opposite plate, thus the overall mechanical performance is effectively improved. However, the impact force of steel frame structure is directly transferred to the side plate, hence, its shear strain is relatively large.

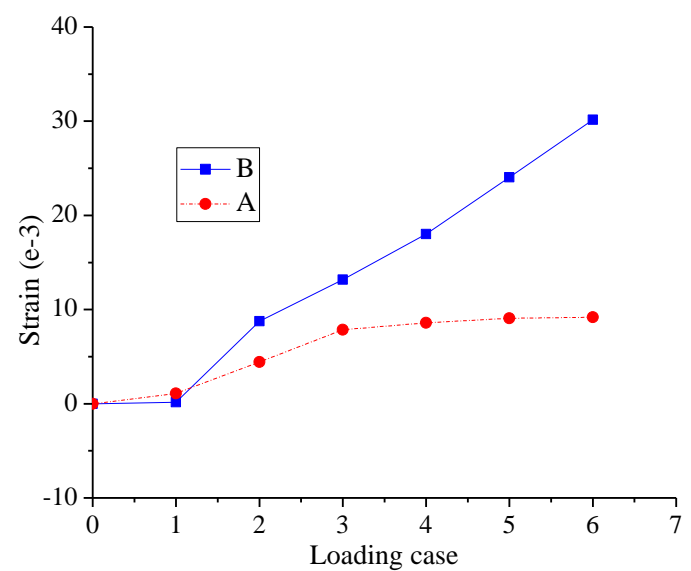

(a)

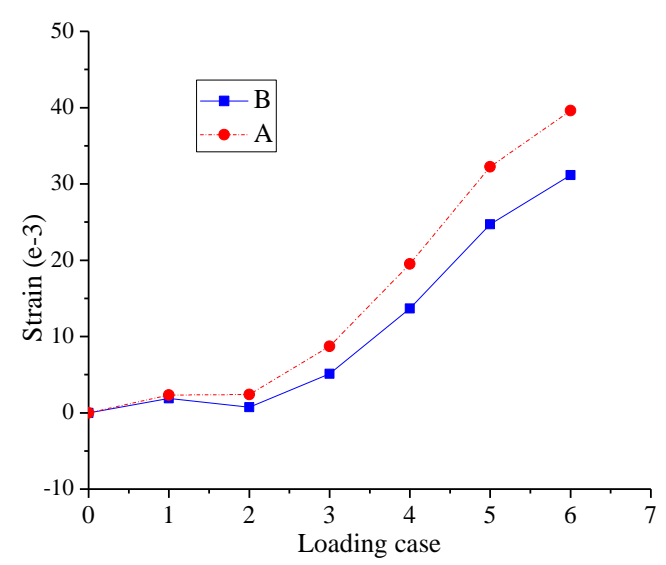

(b)

Figure 6. Strain curves. (a) Maximum normal strain at back surface of the impact position; and (b) maximum shear strain at the corresponding side plate of the impact position.

\subsection{Local Deformation of Joint}

Figure 7 shows the deformation of the impacted column at column base after case G6, it can be found that the screws of Model A's impacted column at the column base joints have bent. This is due 
to the fact that the bending resistance of the steel frame structure decreases and the catenary action increases sharply, which would increase the axial force, leading to the screws of Model A's impacted column at the column base joints being subjected to the interaction of the axial force, shear force, and bending moment; however, the screws of Model B's impacted column at the column base joints are mainly subjected to shear force and bending moment.

Figure 8 shows the damage of second floor slab around the impacted column at the end of case G6. It is shown that the slab damage at second floor slab around the impacted column of ordinary steel frame structure is worse than that of polyurethane-steel sandwich structure, and its rivets on the second floor slab around the impact column have been exposed. Similar to Figure 7, the reason for this phenomenon is that the impacted column of steel frame structure is seriously damaged, and its axial force increases sharply caused by the catenary action, which results in the serious damage of the second floor slab around the impacted column. This implies that the polyurethane-steel sandwich structure could maintain superior overall mechanical performance and transfer the impact force to the support and the frame beam stably.

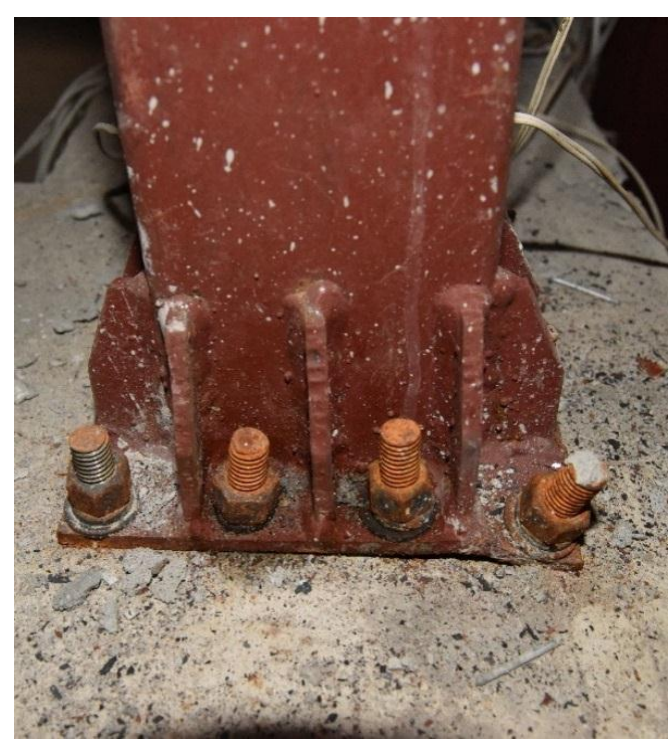

(a)

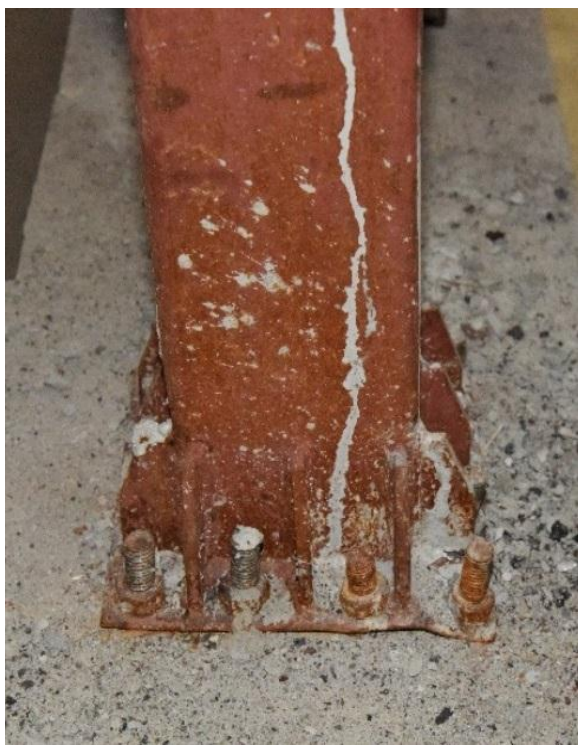

(b)

Figure 7. The deformation of the impacted column at column base. (a) Model A; and (b) Model B.

Figure $9 \mathrm{a}, \mathrm{b}$ shows the maximum normal strain at the impacted column base joint and the maximum shear strain of its side plate under each impact, respectively. Figure 10a,b plots the maximum normal strain at the top of first floor impacted column and the maximum shear strain of its side plate under each impact, respectively. From these figures, some interesting phenomena are observed:

(1) As the impact progresses, for steel frame structure, its maximum normal strain at the impacted column base joint and the top of first floor impacted column gradually increases and exceeds the corresponding strain at the corresponding position of polyurethane-steel sandwich structure. This is because, with the mass of steel ball and the impact force increase, the local deformation of steel frame structure increases and the bending resistance of the column midspan is substantially weakened, hence, the contribution of catenary action to resist the impact increases gradually, which requires the column to provide great tension.

(2) However, for the polyurethane-steel sandwich structure, its maximum shear strain at the impacted column base joint and the top of first floor impacted column is much greater than that of the corresponding strain at the corresponding position of steel frame structure, which indirectly proved that the shear force and bending moment of the polyurethane-steel sandwich structure at the joint 
area is much greater than that of steel frame structure, indicating that polyurethane-steel sandwich structure has better integrity and excellent impact transmission capability.

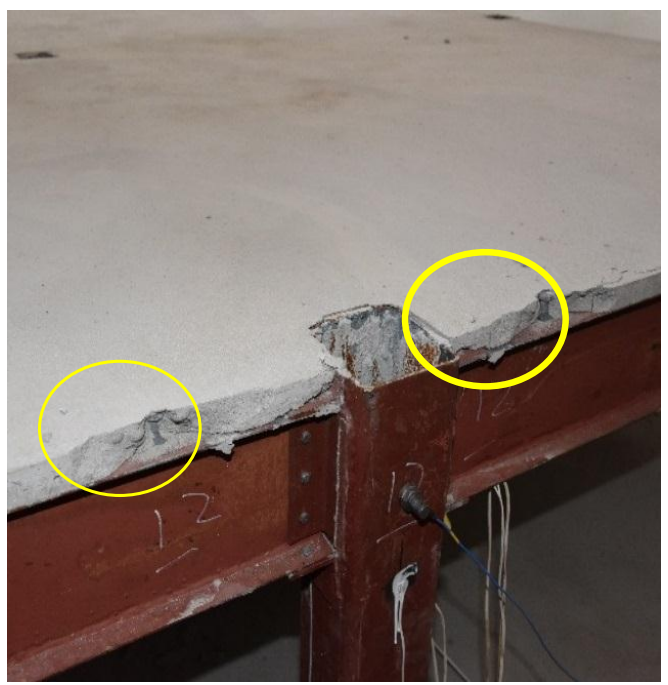

(a)

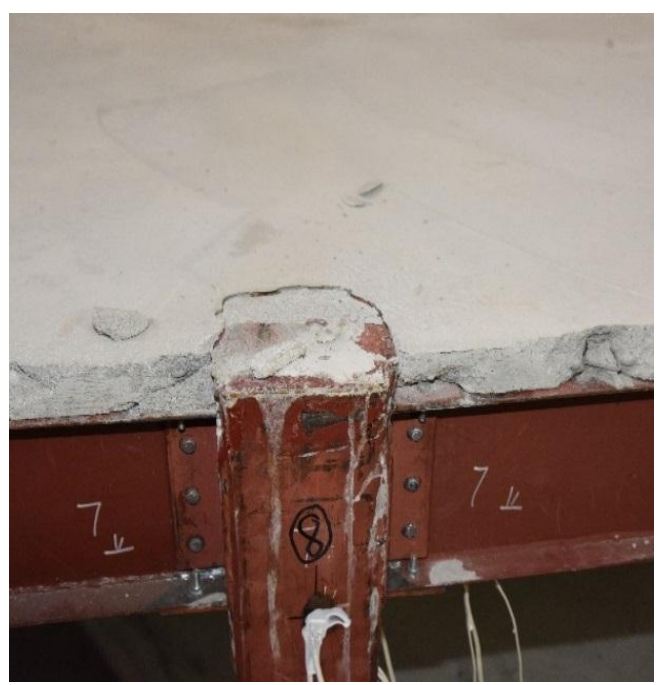

(b)

Figure 8. The damage of second floor slab around the impacted column at the end of case G6. (a) Model A; and (b) Model B.

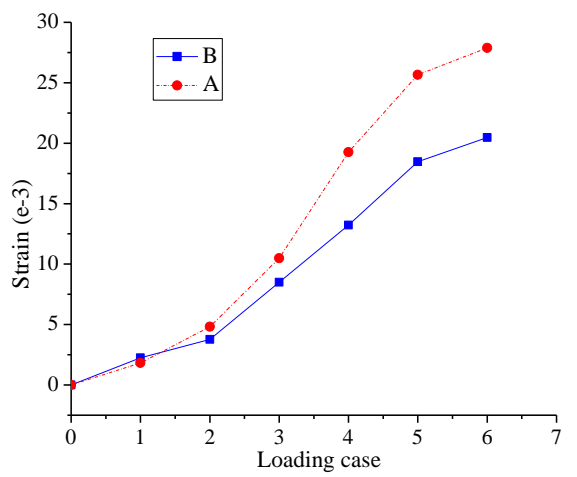

(a)

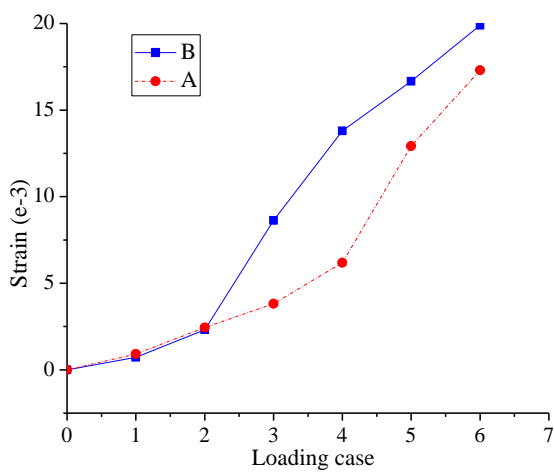

(b)

Figure 9. Strain curves at the impacted column base joint. (a) The maximum normal strain; and (b) the maximum shear strain of its side plate.

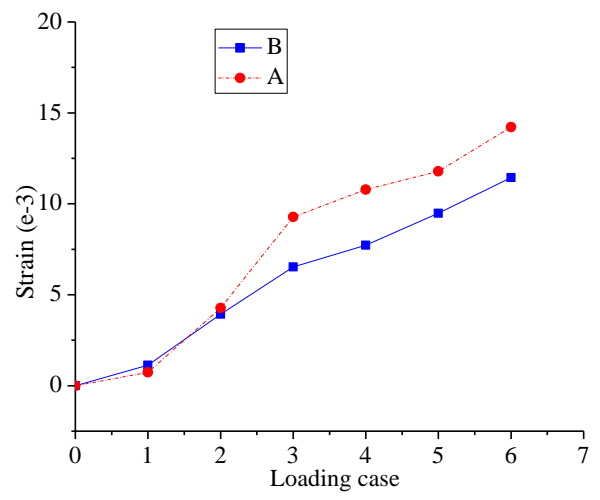

(a)

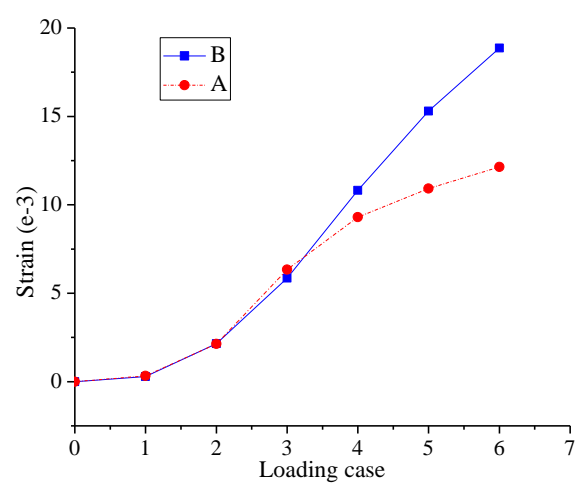

(b)

Figure 10. Strain curves at the top of first floor impacted column. (a) The maximum normal strain; and (b) the maximum shear strain of its side plate. 


\subsection{Overall Structural Deformation}

In Figure 11, the overall deformation of the impacted column and its connected members at the end of case G6 are shown. It clearly demonstrates that the rotation angle between the impacted column and its connected beam of Model A is larger than that of Model B. Combining the analysis in Section 3.1, since the excessive local dent of Model A's impacted column leads to the decrease of bending resistance capacity, the catenary action of column plays a more important role in resisting the impact. At the same time, the constraint capacity of Model A's column on its beam is weak. Therefore, the angle between the beams and columns is relatively large.

As depicted in Figure 12, the vertical deformations of Model A and Model B at the end of all impact cases are measured as approximately $14 \mathrm{~mm}$ and $6 \mathrm{~mm}$, respectively. This is because, as for the steel frame structure, the excessive local dent of the impacted column makes the catenary action more obvious, which results in increased column tension, and the displacement of the upper structure increases under the action of tension. However, the catenary action of polyurethane-steel sandwich structure is alleviated, and the displacement is mainly caused by the bending deformation.

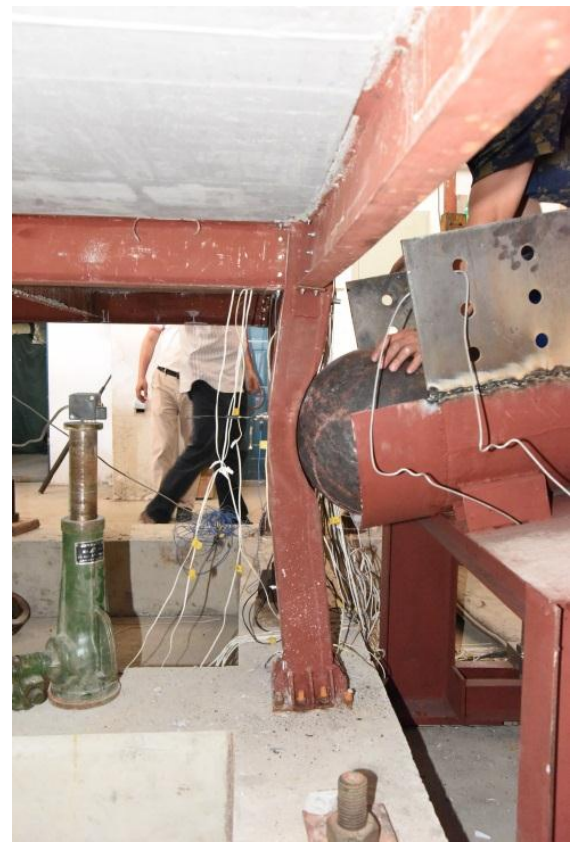

(a)

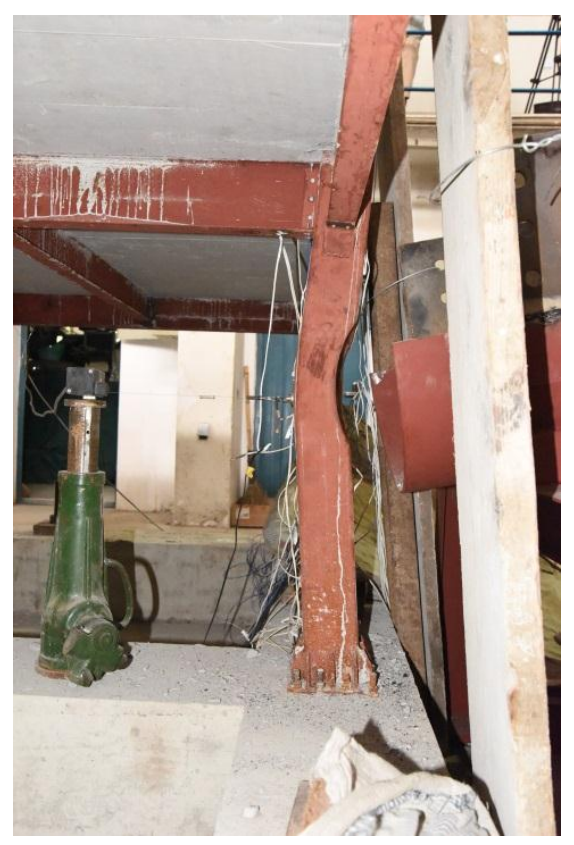

(b)

Figure 11. Photo of the impacted column after case G6. (a) Model A; and (b) Model B.
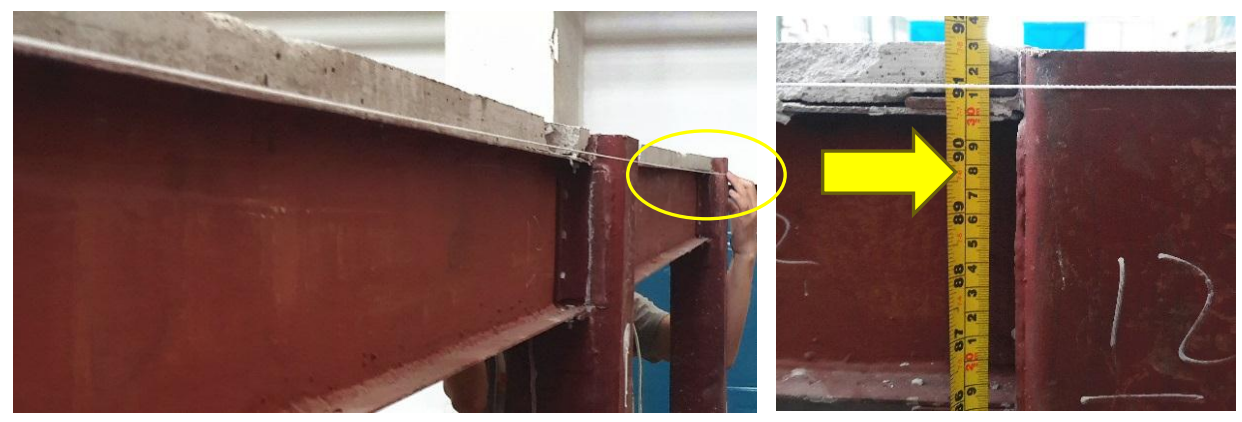

(a)

Figure 12. Cont. 


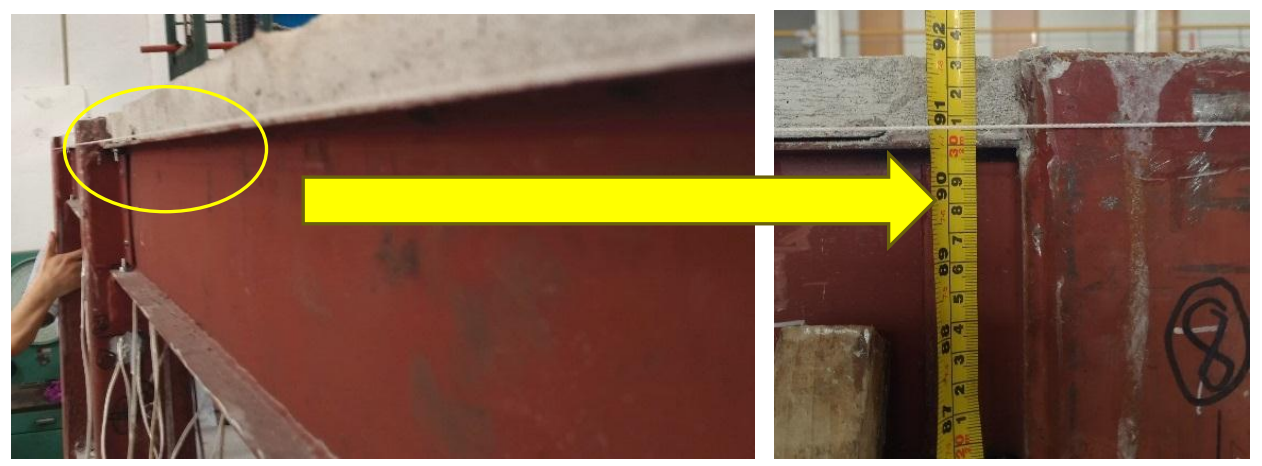

(b)

Figure 12. The vertical deformations at the end of case G6. (a) Model A; and (b) Model B.

Figure $13 \mathrm{a}, \mathrm{b}$ displays the maximum normal strain of the $\mathrm{B} / 2$ and $\mathrm{A} / 3$ column base, which is adjacent to the impacted column. It is noted that because of the polyurethane elastomer's role in transmitting force and enhancing integrity, the maximum normal strain at these positions of the steel frame structure is smaller than that of polyurethane-steel sandwich structure. Correspondingly, the normal stress at these positions of the steel frame structure is relatively small. Figure $13 \mathrm{c}$ shows the maximum normal strain at the beam bottom flange near the beam-column joint, which is directly connected with the impacted column. This demonstrates that, under each impact, for the polyurethane-steel sandwich structure, the absolute increase of normal strain at that position is larger than that of steel frame structure (the negative strain represents the compression of beam). In other words, the larger the impact force, the better the performance of polyurethane-steel sandwich structure, which is obviously beneficial to practical engineering applications. These results mainly occur because the column of polyurethane-steel sandwich structure has a greater ability to restrain the beam, resulting in a greater bending moment of the beam, and the bending moment here would cause the compression of the bottom flange.

Figure 14 shows the displacement, velocity and acceleration time-history at the top of each floor of the A/3 column under case G2. From these figures, it can be seen that for polyurethane-steel sandwich structure (Model B), both the displacement, velocity, and acceleration time-history at the top of each floor of the A/3 column are greater than the corresponding time-history at the corresponding position of steel frame structure (Model A), indicating that polyurethane-steel sandwich structure has better integrity and excellent impact transmission capability. This is consistent with other phenomena in the paper, such as Figure 9a,b.

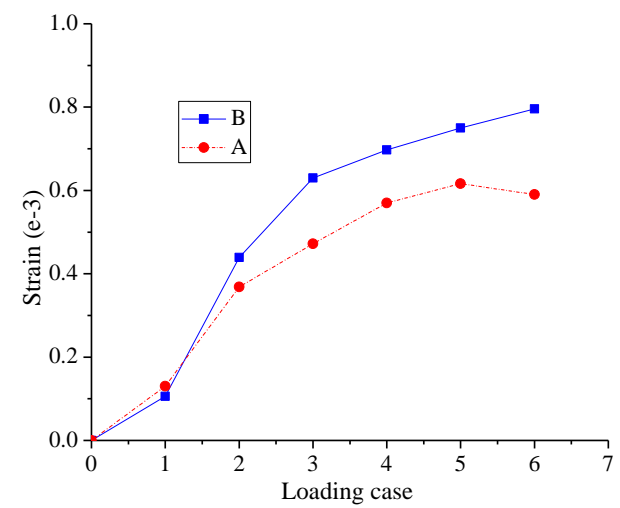

(a)

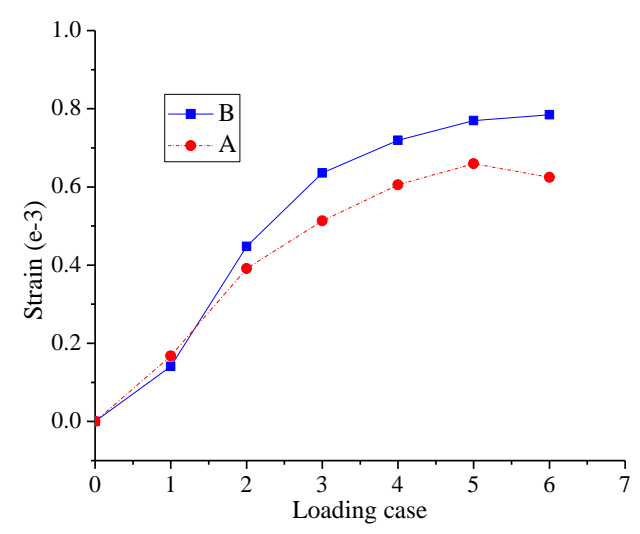

(b)

Figure 13. Cont. 


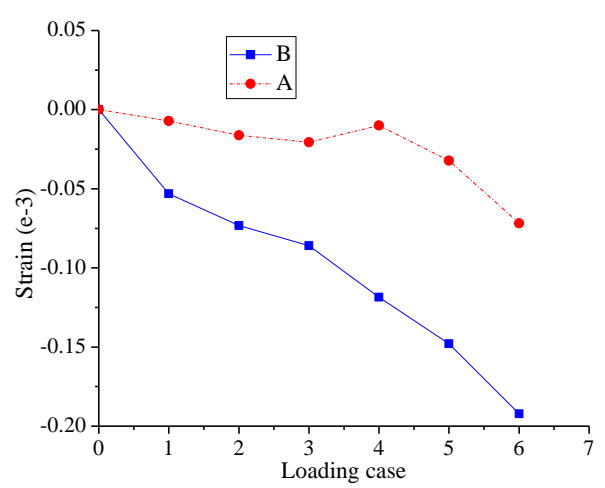

(c)

Figure 13. The maximum normal strain under each impact. (a) B/2 column base; (b) A/3 column base; and (c) the A end of the 2/A-B beam at the first floor.

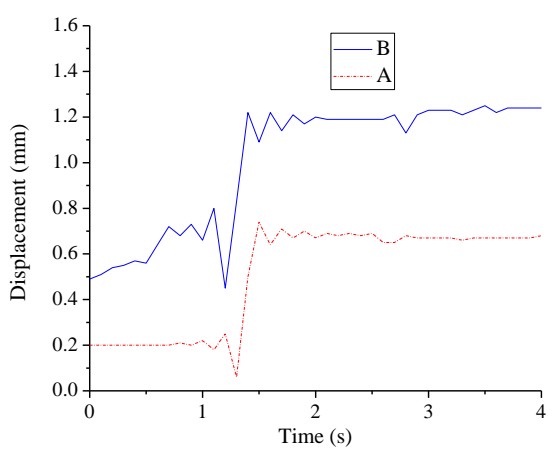

(a)

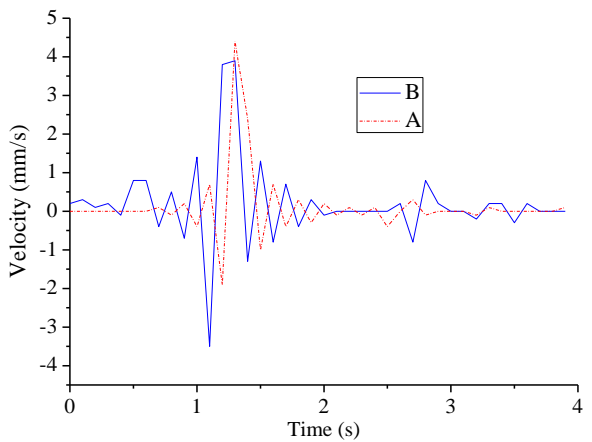

(c)

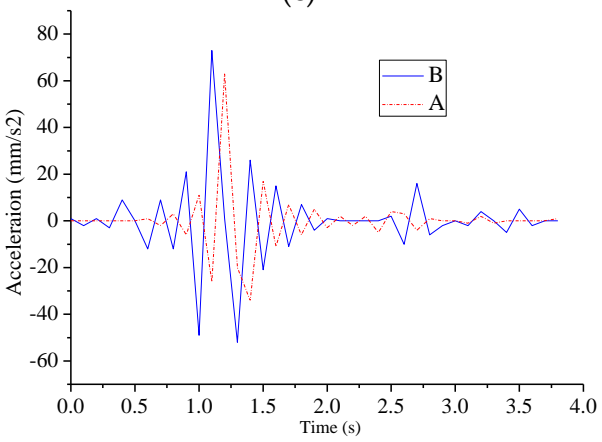

(e)

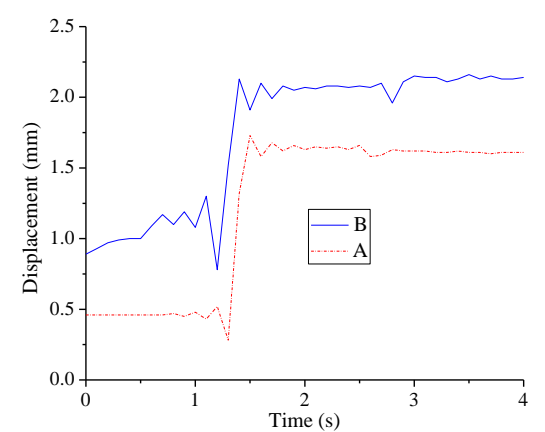

(b)

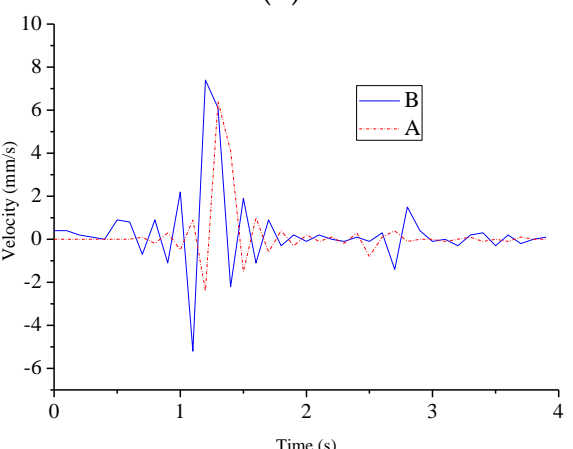

(d)

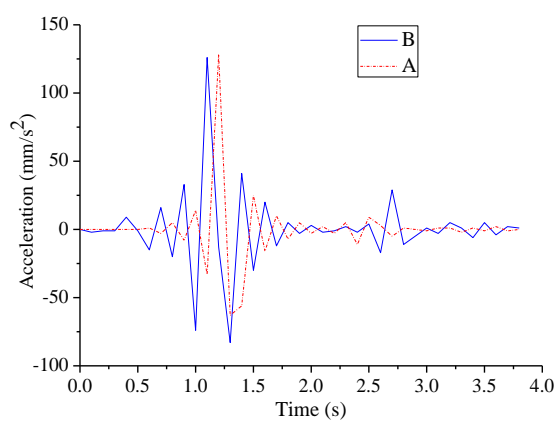

(f)

Figure 14. Response of the A/3 column in case G2: (a) displacement time-history at the top of the first floor; (b) displacement time-history at the top of the second floor; (c) velocity time-history at the top of the first floor; (d) velocity time-history at the top of the second floor; (e) acceleration time-history at the top of first floor; and (f) acceleration time-history at the top of the second floor. 


\section{Conclusions}

This paper proposes a creative polyurethane-steel sandwich composite structure to strengthen the impact resistance of buildings under debris flow. To make a comparative experimental study of the dynamic behaviors of such a polyurethane-steel sandwich structure and steel frame structure under the impact of simulated debris flow, a series of impact loading tests are designed and carried out. By analyzing the test results, the following conclusions can be drawn, which can provide a reference for future engineering applications:

(1) The steel frame structure mainly depends on the impacted column to resist the impact loading.

For steel frame structure, large local damage occurs under high or continuous impact loading; the local bending resistance of the impacted column decreases sharply, and instability may occur; furthermore, the mechanical behaviors and structural load-transferring path change, and the catenary action on the impacted column is quite obvious; the impact force is primarily borne by the impacted column, and the deformation is mainly concentrated on the impacted column.

(2) Under debris flow impact, the polyurethane-steel sandwich structure exhibits superior performance to resist the impact loading.

Under lower debris flow impact intensity, its deformation damage is minor, and does not affect its serviceability; under large and continuous impact loading, depending on the low compression performance of the polyurethane elastomer filled in column, it can coordinate the deformation of the column so as not to cause a great dent in local parts; it can ensure the bending resistance and vertical bearing capacity of column not decrease significantly, transferring the impact force more reliably to the whole structure; also, the dissipation of impact energy depends on overall force and deformation; meanwhile, the stress and strain of polyurethane-steel sandwich structure develop more uniformly.

In conclusion, the experimental study indicates that the polyurethane-steel sandwich structure can relieve the impact effect in time and space, and remarkably strengthens the overall mechanical performance of the whole structure under debris flow, compared with traditional steel frame structure. For the newly-built structures, the polyurethane-steel sandwich structures are favorable, which has bright prospects and deserves further study for its application in civil engineering. However one should be aware of that this is still the preliminary stage of the engineering design. During the next stages a more detailed parametric analysis for design would be necessary.

Acknowledgments: Financial support from the National Key Technology R\&D Program through grant 2014BAL05B01 is highly appreciated.

Author Contributions: Peizhen Li conceived the new structural system, designed the work and revised the paper; Shutong Liu performed the experimental study and theoretical analysis, drafting the paper; Zheng Lu proposed the method, analyzed the data and revised the paper critically for important intellectual content. All authors approve the final version to be published and have agreement to be accountable for all aspects of the work in ensuring that questions related to the accuracy or integrity of any part of the work are appropriately investigated and resolved.

Conflicts of Interest: The authors declare no conflict of interest.

\section{References}

1. Iverson, R.M. The physics of debris flow. Rev. Geophys. 1997, 35, 245-296. [CrossRef]

2. Hu, K.H.; Cui, P.; Zhang, J.Q. Characteristics of damage to buildings by debris flows on 7 August 2010 in Zhouqu, Western China. Nat. Hazards Earth Syst. Sci. 2012, 12, 2209-2217. [CrossRef]

3. Zanchetta, G.; Sulpizio, R.; Pareschi, M.T.; Leoni, F.M.; Santacroce, R. Characteristics of May 5^6, 1998 volcaniclastic debris flows in the Sarno area (Campania, southern Italy): Relationships to structural damage and hazard zonation. J. Volcanol. Geotherm. Res. 2004, 133, 377-393. [CrossRef]

4. Chen, X.Z.; Cui, Y.F. The formation of the Wulipo landslide and the resulting debris flow in Dujiangyan City, China. J. Mt. Sci. 2017, 14, 1100-1112. [CrossRef]

5. Wang, W.X.; Hua, X.G.; Wang, X.Y.; Chen, Z.Q.; Song, G.B. Optimum design of a novel pounding tuned mass damper under harmonic excitation. Smart Mater. Struct. 2017, 26. [CrossRef] 
6. Song, G.B.; Zhang, P.; Li, L.Y.; Singla, M.; Patil, D.; Li, H.N.; Mo, Y.L. Vibration Control of a Pipeline Structure Using Pounding Tuned Mass Damper. J. Eng. Mech. 2016, 142. [CrossRef]

7. Zhang, P.; Song, G.B.; Li, H.N.; Lin, Y.X. Seismic Control of Power Transmission Tower Using Pounding TMD. J. Eng. Mech. 2013, 139, 1395-1406. [CrossRef]

8. Lu, Z.; Wang, D.C.; Masri, S.F.; Lu, X.L. An experimental study of vibration control of wind-excited high-rise buildings using particle tuned mass dampers. Smart Struct. Syst. 2016, 18, 93-115. [CrossRef]

9. Lu, Z.; Chen, X.Y.; Zhang, D.C.; Dai, K.S. Experimental and analytical study on the performance of particle tuned mass dampers under seismic excitation. Earthq. Eng. Struct. Dyn. 2017, 46, 697-714. [CrossRef]

10. Lu, Z.; Lu, X.L.; Jiang, H.J.; Masri, S.F. Discrete element method simulation and experimental validation of particle damper system. Eng. Comput. 2014, 31, 810-823. [CrossRef]

11. Lu, Z.; Chen, X.Y.; Lu, X.L.; Yang, Z. Shaking table test and numerical simulation of an RC frame-core tube structure for earthquake-induced collapse. Earthq. Eng. Struct. Dyn. 2016, 45, 1537-1556. [CrossRef]

12. Chen, H.K.; Tang, H.M.; Chen, Y.Y. Research on method to calculate velocities of solid phase and liquid phase in debris flow. Appl. Math. Mech. 2006, 27, 399-408. [CrossRef]

13. Hungr, O.; Morgan, G.C.; Kellerhals, R. Quantitative analysis of debris torrent hazards for design of remedial measures. Can. Geotech. J. 2011, 21, 663-677. [CrossRef]

14. Moriguchi, S.; Borja, R.I.; Yashima, A.; Sawada, K. Estimating the impact force generated by granular flow on a rigid obstruction. Acta. Geotech. 2009, 4, 57-71. [CrossRef]

15. Laigle, D.; Lachamp, P.; Naaim, M. SPH-based numerical investigation of mudflow and other complex fluid flow interactions with structures. Comput. Geosci. 2007, 11, 297-306. [CrossRef]

16. Pasculli, A.; Minatti, L.; Sciarra, N.; Paris, E. SPH modeling of fast muddy debris flow:Numerical and experimental comparison of certain commonly utilized approaches. Ital. J. Geosci. 2013, 132, 350-365. [CrossRef]

17. Wang, W.; Chen, G.; Han, Z.; Zhang, H.; Jing, P.D. 3D numerical simulation of debris-flow motion using SPH method incorporating non-Newtonian fluid behavior. Nat. Hazards 2016, 81, 1-18. [CrossRef]

18. Dai, Z.; Huang, Y.; Cheng, H.; Xu, Q. SPH model for fluid-structure interaction and its application to debris flow impact estimation. Landslides 2016, 14, 1-12. [CrossRef]

19. Hu, K.; Wei, F.; Li, Y. Real-time measurement and preliminary analysis of debris-flow impact force at Jiangjia Ravine, China. Earth Surface Process. Landf. 2011, 36, 1268-1278. [CrossRef]

20. Chen, H.K.; Xian, X.F.; Tang, H.M.; Zhang, Y.P.; He, X.Y.; Wen, G.J.; Tang, L. Energy distribution in spectrum of shock signal for non-viscous debris flow. J. Vib. Shock. 2012, 31, 56-59.

21. Spence, R.J.S.; Baxter, P.J.; Zuccaro, G. Building vulnerability and human casualty estimation for a pyroclastic flow: a model and its application to Vesuvius. J. Volcanol. Geother. Res. 2004, 133, 321-343. [CrossRef]

22. Luna, B.Q.; Blahut, J.; Westen, C.J.V.; Asch, T.W.J.V.; Akbas, S.O. The application of numerical debris flow modelling for the generation of physical vulnerability curves. Nat. Hazards Earth Syst. Sci. 2011, 11, 2047-2060. [CrossRef]

23. Kang, H.S.; Kim, Y.T. The physical vulnerability of different types of building structure to debris flow events. Nat. Hazards 2016, 80, 1-19. [CrossRef]

24. Zeng, C.; Cui, P.; Su, Z.; Lei, Y.; Chen, R. Failure modes of reinforced concrete columns of buildings under debris flow impact. Landslides 2015, 12, 561-571. [CrossRef]

25. Zhang, Y.; Wei, F.; Wang, Q. Experimental Research of Reinforced Concrete Buildings Struck by Debris Flow in Mountain Areas of Western China. Wuhan Univ. J. Nat. Sci. 2007, 12, 645-650. [CrossRef]

26. Brunkal, H.; Santi, P. Exploration of design parameters for a dewatering structure for debris flow mitigation. Eng. Geol. 2016, 208, 81-92. [CrossRef]

27. Wang, F.; Chen, X.; Chen, J.; You, Y. Experimental study on a debris-flow drainage channel with different types of energy dissipation baffles. Eng. Geol. 2017, 220, 43-51. [CrossRef]

28. Leonardi, A.; Wittel, F.K.; Mendoza, M.; Vetter, R.; Herrmann, H.J. Particle-Fluid-Structure Interaction for Debris Flow Impact on Flexible Barriers. Comput.-Aided Civ. Infrastruct. Eng. 2014, 31, 323-333. [CrossRef]

29. Jiang, Y.J.; Towhata, I. Experimental Study of Dry Granular Flow and Impact Behavior Against a Rigid Retaining Wall. Rock Mech. Rock Eng. 2013, 46, 713-729. [CrossRef]

30. Johnson, P.A.; Mccuen, R.H. Slit Dam Design for Debris Flow Mitigation. J. Hydraul. Eng. 1989, 115, 1293-1296. [CrossRef] 
31. Huang, H.P.; Yang, K.C.; Lai, S.W. Impact force of debris flow on filter dam. Eur. Geosci. Union Gen. Assem. 2007, 9, 1-32.

32. Li, P.; Li, T.Z.H.; Lu, Z.; Li, J. Study on Dynamic Response of Novel Masonry Struct. Impacted by Debris Flow. Sustainability 2017, 9, 1122. [CrossRef]

33. Lu, Z.; Yang, Y.L.; Lu, X.L.; Liu, C.Q. Preliminary Study on the Damping Effect of a Lateral Damping Buffer under a Debris Flow Load. Appl. Sci. 2017, 7, 201. [CrossRef]

34. Datta, J.; Haponiuk, J. Advanced coating of interior of tanks for rising environmental safety-novel applications of polyurethanes. Polish Marit. Res. 2008, 15, 8-13. [CrossRef]

35. Sharma, S.C.; Krishna, M.; Murthy, H.N.N.; Sathyamoorthy, M.; Bhattacharya, D. Fatigue studies of polyurethane sandwich structures. J. Mater. Eng. Perform. 2004, 13, 637-641. [CrossRef]

36. Szarnik, A.; Kuryłko, A. Application of steel sandwich panels to hull structure of two-segment inland navigation passenger ship. Polish Marit. Res. 2006, S2, 85-87.

37. Alia, C.; Arenas, J.M.; Suárez, J.C.; Pinilla, P. Mechanical behavior of polyurethane adhesive joints used in laminated materials for marine structures. Ocean Eng. 2016, 113, 64-74. [CrossRef]

38. Xiao, Y.K.; Ji, W.F.; Chang, K.S.; Hsu, K.T.; Yeh, J.M.; Liu, W.R. Sandwich-structured rGO/PVDF/PU multilayer coatings for anti-corrosion application. Rsc. Adv. 2017, 7, 33829-33836. [CrossRef]

39. Xu, X.J.; Shan, C.L. Impact analysis of the bridge pier anti-collision floating box sets made by sandwich structure with curved-shaped. J. Hunan Univ. Nat. Sci. 2015, 42, 106-111.

40. Harris, D.K.; Cousins, T.; Sotelino, E.D.; Murray, T.M. Flexural lateral load distribution characteristics of sandwich plate system bridges: parametric investigation. J. Bridge Eng. 2010, 15, 684-694. [CrossRef]

41. Onoue, K.; Tamai, H.; Suseno, H. Shock-absorbing capability of lightweight concrete utilizing volcanic pumice aggregate. Construct. Build. Mater. 2015, 83, 261-274. [CrossRef]

42. He, N.; Chen, N.; Zeng, C. Current Situation and Tendencies of Debris Flow Initiation Mechanism. J. Catastrophol. 2013, 28, 121-125.

(C) 2017 by the authors. Licensee MDPI, Basel, Switzerland. This article is an open access article distributed under the terms and conditions of the Creative Commons Attribution (CC BY) license (http:/ / creativecommons.org/licenses/by/4.0/). 